Wu, H. X., A. C. Matheson and D. Spencer (1998): Inbreeding in Pinus radiata. I. The effect of inbreeding on growth, survival and variance. Theoretical and Applied Genetics 97: 1256-1268.

Wu, H. X., J. V. Owen, A. Abarquez and A. C. Matheson (2004): Inbreeding in Pinus radiata. V. The effects of inbreeding on fecundity. Silvae Genetica 53: 80-87.
Wu, H. X., K. G. Eldridge, A. C. Matheson, M. B. Powell, T. A. McRae, T. B. Butcher and I. G. Johnson (2007): Achievements in forest tree improvement in Australia and New Zealand. 8. Successful introduction and breeding of radiata pine in Australia. Australian Forestry 70: 215-225.

\title{
The Effects of Drying Temperature and Method of Assessment on the Expression of Genetic Variation in Gross Shrinkage of Eucalyptus globulus Wood Samples
}

\author{
By M. G. Hamilton ${ }^{1), *)}$, C. E. Harwood ${ }^{2)}$ and B. M. PotTs ${ }^{1)}$
}

(Received $26^{\text {th }}$ September 2008)

\begin{abstract}
Genetic variation in wood-sample gross shrinkage and basic density was examined in a Eucalyptus globulus base population trial growing in Tasmania, Australia. Gross shrinkage, which includes all components of shrinkage including collapse, was assessed in four ways (calliper- and visually-assessed tangential shrinkage, volumetric shrinkage and radial shrinkage) on samples dried at three temperatures $\left(22^{\circ} \mathrm{C}, 60^{\circ} \mathrm{C}\right.$ and $\left.105^{\circ} \mathrm{C}\right)$. Significant differences between subraces were observed using all measures of gross shrinkage for two or more of the three drying treatments. Furthermore, significant additive genetic variation within subraces was observed in calliper- and visually-assessed gross shrinkage under two or more of the drying treatments, with narrowsense heritabilities greater than or equal to 0.35 . There was no obvious trend in heritabilities or coefficients of additive genetic variation with drying temperature. Under the $105^{\circ} \mathrm{C}$ drying treatment, subrace correlations among calliper-, visually- and volume-assessed gross shrinkage were positive and very strong $(\geq 0.97)$, while
\end{abstract}

\footnotetext{
1) School of Plant Science and Cooperative Research Centre for Forestry, University of Tasmania, Private Bag 55, Hobart TAS 7001 Australia. Phone: 613 62262603. Fax: 61362262698.

2) CSIRO Sustainable Ecosystems and Cooperative Research Centre for Forestry, Private Bag 12, Hobart, TAS, 7001 Australia.

*) Corresponding author: Matthew G. Hamilton. E-Mail: matthew.hamilton@utas.edu.au
}

these measures were less strongly correlated with radial gross shrinkage at the subrace level $(\leq 0.77)$. Withinsubrace genetic correlations among the first three measures were also strongly positive $(\geq 0.95)$. These high genetic correlations suggest that different drying regimes and the calliper, visual and volume methods of assessment could be used interchangeably to select for reduced tangential gross shrinkage. Estimated subrace and genetic correlations between basic density and measures of gross shrinkage were universally negative (i.e. favourable), although not all were significantly different to zero.

Key words: Heritability, genetic correlation, genotype-by-drying-regime interaction, drying defect, shrinkage, collapse, basic density.

\section{Introduction}

There are large areas of $E$. globulus plantation in Australia (c. 454000 ha in 2005; PARSONs et al., 2006), Chile (c. 232,000 ha in 2003), Portugal (c. 700,000 ha in 2002) and Spain (c. 500,000 ha in 2002) (PoTTs et al., 2004). Although pulpwood production is the principal focus of most $E$. globulus growers, there is increasing interest in producing plantation-grown solid-wood products, such as appearance-grade sawn timber (RAYMOND, 2000; GREAVES et al., 2004a; NolAn et al., 2005). Breeding, along with improved silviculture and the adoption of appropriate processing practices, is a possible means of improving the profitability of such plantations. 
Although sawmilling studies have shown that adequate recoveries of dried appearance-grade products are possible from $E$. globulus grown in appropriately managed plantations (WAUGH and YANG, 1994; MoORE et al., 1996; BRENNAN et al., 2004; NUTTO and VAZQUEZ, 2004; WASHUSEN, 2004; WAUGH, 2004), increasing product recovery and value by reducing drying degrade is likely to be an objective of appearance-grade sawn-timber breeders (RAYMOND, 2000; GREAVES et al., 2004a). The presence of drying defects such as cupping, face checking (i.e. exposed cracks) and internal checking can cause degrade in, and reduce the value of, appearance-grade sawn timber (WASHUSEN et al., 2000; NUTTO and VAZQUEZ, 2004; WAUGH, 2004; NolaN et al., 2005). Such drying defects are caused by within-board variation in shrinkage (CHAFE, 1992; Svensson and MARTENSSON, 1999; NolAN et al., 2005).

Upon drying, wood shrinks as a result of a number of fundamentally different processes. Collapse occurs early in the drying process if tensile forces, generated as free water is removed from highly impermeable wood fibres, exceed the strength of cell walls, causing them to become distorted (CHAFE, 1992; ILIC, 1999). Treatment with steam (i.e. reconditioning; NolAN et al., 2003) is commonly undertaken by sawmillers to recover collapse after preliminary drying, but non-recoverable collapse or 'abnormal shrinkage' sometimes remains in boards. Abnormally high levels of shrinkage in E. globulus wood are often attributed to the presence of tension wood (CHAFe, 1992; WASHUSEN and Ilic, 2001; WALKER, 2006). Normal shrinkage refers to a reduction in the thickness of cell walls that occurs as bound water is removed from them. It generally occurs late in the drying process after most, or all, free water has been removed from cell cavities (i.e. below the fibre saturation point; CHAFE, 1992; WALKER, 2006). The expression of normal shrinkage varies with moisture content below the fibre saturation point because cell walls swell if they regain moisture after drying.

Gross shrinkage incorporates all components of shrinkage including recoverable collapse, non-recoverable collapse, and 'abnormal' and 'normal' shrinkage. However, gross shrinkage is simply referred to as collapse by some authors, based on the assumption that collapse is the principal cause of the gross shrinkage observed in their studies (KUBE and RAYMOND, 2005). Furthermore, gross shrinkage has been shown to be strongly genetically correlated with recoverable collapse in 12-mm wood cores of $E$. nitens (HAMILTON et al., 2009).

The measurement of gross shrinkage in wood samples, such as $12 \mathrm{~mm}$ cores, has been proposed as a means of identifying genotypes that are less prone to expressing drying defects (KUBE and RAYMOND, 2005). Wood cores are routinely extracted from trees in pulpwood breeding programs to assess physical and chemical wood properties (DownEs et al., 1997; RAYMOND and APIOLAZA, 2004) and gross shrinkage in cores can be measured at minimal additional cost.

The improvement of pulpwood traits, such as rotationage volume, basic density and pulp yield (BORRALHO et al., 1993; Greaves and Borralho, 1996; Greaves et al., 1997), has historically been the focus of most $E$. globulus breeding programs. Improvement of these traits may also have favourable implications for sawn-timber producers. Increased growth is desirable for sawn-timber production and increased basic density has been shown to have a favourable relationship with sawn-timber hardness, stiffness and strength properties (DICKSON et al., 2003; McKenzIE et al., 2003). Furthermore, pulpwood is likely to be a valuable by-product in most sawntimber production systems. However, the extent to which concurrent genetic gains can be made in a single breeding population in both appearance-grade traits (e.g. drying defects) and pulpwood traits will depend on the strength and direction of genetic correlations among these traits.

The principal aims of this study were to (1) determine if three drying treatments and four methods of assessment revealed genetic variation in sample gross shrinkage, (2) examine if genetic variation in gross shrinkage was stable across drying treatments and methods of assessment, and (3) examine the relationship between gross shrinkage and basic density, a common pulpwood selection trait.

\section{Materials and Methods}

Trial

This study was undertaken on trees planted in a Gunns Ltd. E. globulus base population progeny trial at West Ridgley in north-western Tasmania (for details, see MACDONALD et al., 1997; and APIOLAZA et al., 2005). It contained the open-pollinated progeny of 451 native forest mothers sampled by the CSIRO Tree Seed Centre in 1987 and 1988 (GARDINER and CRAWFORD, 1987; GARDINER and CRAWFORD, 1988). The mothers were sampled from 13 races and 22 subraces (refer to DUTKOWsKI and POTTS (1999) and http://members.forestry.crc.org.au/ globulus).

The trial was divided into two blocks approximately $150 \mathrm{~m}$ apart containing two and three replicates respectively. Replicates were comprised of 17 incomplete blocks and families were planted in two-tree plots. Seedlings were established at a spacing of 2 by $4.5 \mathrm{~m}$ and the trial was managed as a pulpwood stand without thinning or pruning. At the time of sampling, 15 years after establishment, $46 \%$ of the original trees and $91 \%$ of the original families were still surviving.

This study examined wood property traits in 250 trees, from 116 families (generally two, but up to three, trees per family) and 10 subraces, felled as part of a sawmilling trial. These were the same trees detailed in HAMiLToN et al. (2007) with one additional tree from each of the King Island and Southern Furneaux subraces. To enable extraction of a sawlog from each tree, only trees of sufficiently good form and with a diameter at breast height $(1.3 \mathrm{~m})$ greater than $21 \mathrm{~cm}$ were selected for felling. A single $1.5 \mathrm{~m}$ long sawlog was cut from the straightest part of the lower stem in each tree (Greaves et al., 2004b; Hamilton et al., 2007). 


\section{Traits}

From each felled tree, one disc approximately $100 \mathrm{~mm}$ thick was cut from directly below the sawlog. Discs were extracted from the base of sawlogs rather than breast height to avoid decay induced from previous sampling for wood property assessment (HAMILTON et al., 2007). The mean height of disc extraction was $12 \%$ of tree height $(3.0 \mathrm{~m})$. Discs were wrapped in plastic bags and stored at $4{ }^{\circ} \mathrm{C}$ as soon as possible after felling to avoid desiccation.

From each disc, three $12 \times 12 \mathrm{~mm}$ north-south oriented bark-to-bark samples were sawn to include the stem pith using a bench-mounted circular saw. After extraction, the samples were placed in water. These samples were sized to approximate $12 \mathrm{~mm}$ cylindrical cores that are routinely extracted from standing trees by $E$. globulus pulpwood breeders for the assessment of physical and or chemical wood properties (DownEs et al., 1997; RAYMOND and APIOLAZA, 2004).

Each bark-to-bark sample was broken into two pithto-bark 'half samples' for ease of handling. Decay was observed near the pith of samples from $51 \%$ of trees and was removed prior to the measurement of green volume using the water displacement method (TAPPI, 1989). The three matching pairs of half samples from each tree were randomly allocated to three drying treatments: (1) $22^{\circ} \mathrm{C}$ for 60 days in a controlled temperature room with a relative humidity of approximately $36 \%$, a drying regime suitable for drying cores for chemical analysis and the assessment of air-dry density (HAMiLTon et al., 2008) (2) $60^{\circ} \mathrm{C}$ for 48 hours in an oven and (3) $105^{\circ} \mathrm{C}$ for 24 hours in an oven, a treatment commonly adopted in breeding programs to assess basic density (DownES et al., 1997; RAYMOND and APIOLAZA, 2004). The green radial length of one half sample selected at random from each tree and drying treatment was measured prior to drying. The mean green radial length of half samples in all drying treatments was $104 \mathrm{~mm}(\mathrm{SD}=23$ or $24 \mathrm{~mm}$ ). Under each drying treatment samples were dried to equilibrium moisture content.

During drying, samples were restrained within aluminium channel of $13 \mathrm{~mm}$ internal width (BANDARA, 2006). Samples were aligned within the aluminium channel to ensure that one of their transverse faces was exposed to the air. Samples that were oven dried at $105^{\circ} \mathrm{C}$ were weighed immediately after drying and their basic densities calculated (TAPPI, 1989). After drying, all samples were stored in an air-conditioned laboratory and allowed to stabilise to equilibrium moisture content (approximately 8\%) before sample dimensions were measured. Gross shrinkage was calculated for each tree and drying treatment using four methods:

(1) Calliper-assessed tangential gross shrinkage was calculated as the difference between the mean of two measures of minimum tangential width (one from each of the half samples from each tree and drying treatment) and green sample width (i.e. $12 \mathrm{~mm}$ ). KUBE and RAYMOND (2005) outlined a similar procedure.

(2) Visually-assessed tangential gross shrinkage. Trees were ranked from best to worst based on subjective visual assessment of gross shrinkage within each drying treatment. High rankings were accorded to trees with obvious tangential gross shrinkage and or washboarding in half samples. These data were then 'normalised' for analysis (i.e. ranks were expressed as proportions of the number of trees plus one, and these proportions were, in turn, expressed as normal deviates, assuming an underlying standard normal distribution).

(3) Volume-assessed gross shrinkage was calculated as the difference between the sum of the two dry halfsample volumes from each tree and drying treatment and the sum of the corresponding green halfsample volumes. Volumes were assessed using the water displacement method (TAPPI, 1989). Volumeassessed gross shrinkage was a composite measure of tangential, radial and longitudinal gross shrinkage.

(4) Radial gross shrinkage was calculated as the differences between the dried and green lengths of each half sample.

Calliper-assessed, volume-assessed and radial gross shrinkage were expressed as percentages of green sample dimensions.

\section{Statistical Analyses}

Univariate restricted maximum likelihood (REML) mixed model analyses of basic density and all measures of gross shrinkage under each drying treatment were undertaken by fitting the following linear model:

$$
\begin{aligned}
\mathrm{Y}= & \mathrm{MEAN}+\mathrm{BLOCK}+\mathrm{HEIGHT}+\mathrm{DECAY}+ \\
& \mathrm{SUBRACE}+\text { FAM }(\text { SUBRACE })+R E S I D U A L
\end{aligned}
$$

where $\mathrm{Y}$ is a vector of observations for the trait, MEAN is the mean of the trait, BLOCK are the block effects fitted as a fixed factor, HEIGHT are the height of disc extraction effects (expressed as a percentage of tree height) fitted as a covariate, DECAY are the decay effects (i.e. two levels: decay removed and decay not removed) fitted as a fixed factor, SUBRACE are the subrace effects fitted as a fixed factor, $F A M(S U B R A C E)$ are the family within subrace effects fitted as a random factor and RESIDUAL is a vector of residuals.

Initially, replicate within block was fitted as a random factor but this term was not included in the model used for final analyses, as it was not significant in any trait. Furthermore, analysis of DECAY as a dependent binary variable using a probit link function did not reveal a significant subrace or family within subrace effect, indicating that DECAY could be fitted as an explanatory variable in the analysis of basic density and gross shrinkage without introducing significant bias according to a genotype's propensity to exhibit decay.

Overall and subrace least-squares means were estimated for each trait. These were estimated for $12 \%$ of tree height assuming no decay was removed from samples, using the PREDICT statement in ASReml (GILmour et al., 2006). The significance of the SUBRACE term in each analysis was gauged with an F-test using the degrees of freedom associated with the $F A M(S U B R A C E)$ term as the denominator degrees of 
freedom. For traits in which the SUBRACE term was significant, Tukey-Kramer honest significant difference tests were undertaken to elucidate which subraces were significantly different to each other.

Additive variance $\left(\sigma_{\mathrm{a}}^{2}\right)$, phenotypic variance $\left(\sigma_{\mathrm{p}}^{2}\right)$, narrow-sense open-pollinated heritability $\left(h^{2}{ }_{\text {op }}\right)$ and coefficient of additive genetic variance $\left(\mathrm{CV}_{\mathrm{a}}\right)$ were estimated as follows:

$$
\begin{aligned}
& \sigma_{\mathrm{a}}^{2}=\frac{\sigma_{\mathrm{f}}^{2}}{\mathrm{r}} \\
& \sigma_{\mathrm{p}}^{2}=\left(\sigma_{\mathrm{f}}^{2}+\sigma_{\mathrm{c}}^{2}\right) \\
& h_{\mathrm{op}}^{2}=\frac{\sigma_{\mathrm{a}}^{2}}{\sigma_{\mathrm{p}}^{2}} \\
& \mathrm{CV}_{\mathrm{a}}=100 \times \frac{\sqrt{\sigma_{\mathrm{a}}^{2}}}{\bar{x}}
\end{aligned}
$$

where $\sigma_{\mathrm{f}}^{2}$ is the family within subrace variance, $\sigma_{\mathrm{e}}^{2}$ is the residual variance, $r$ is the coefficient of relationship which was fixed to 0.4 to account for an assumed selfing rate of $30 \%$ (GRIFFIN and CoTTERILL, 1988), and $\bar{x}$ is the trait least-squares mean estimated for $12 \%$ of tree height with no decay. The significance of the family within subrace variance and, by implication, additive variance for each trait was tested with a one-tailed likelihood ratio test (GILMOUR et al., 2006).

Intertrait Pearson's correlation coefficients among subrace least square means, herein referred to as 'subrace correlations', were calculated using the PROC CORR procedure in $\mathrm{SAS}^{\mathrm{TM}}$ (Version 9.1). Intertrait Pearson's correlation coefficients among phenotypic observations were calculated in the same manner. Two- tailed t-tests were used to test subrace and phenotypic correlations against zero.

A bivariate model, which extended the univariate model and estimated covariation between family and residual effects, was used to estimate pairwise withinsubrace family correlations between traits and drying treatments (GILMOUR et al., 2006). As families in the trial were open pollinated, estimates of 'family correlations' were considered equivalent to estimates of withinsubrace additive 'genetic correlations' (FALCONER and MACKAY, 1996). One-tailed likelihood ratio tests were used to determine if genetic correlations were significantly different to one or minus one (GILMour et al., 2006). Two-tailed t-tests were undertaken to test if genetic correlations were significantly different to zero, because difficulties with convergence precluded the use of likelihood ratio tests. Analyses were conducted using ASReml (GILMOUR et al., 2006) and SAS ${ }^{\mathrm{TM}}$ (Version 9.1).

\section{Results}

Mean gross shrinkage increased with drying temperature. Mean radial gross shrinkage was less than calliper- and volume-assessed gross shrinkage under all drying treatments (Table 1).

Significant $(\mathrm{P}<0.05)$ differences between subraces were observed using all measures of gross shrinkage for two or more of the three drying treatments (Table 1). When dried at $105^{\circ} \mathrm{C}$, Strzelecki Ranges exhibited the least, and King Island and Cape Patton the most, gross shrinkage regardless of assessment method (Table 2). Between these extremes, subraces were not significantly different to each other in radial gross shrinkage and the ranking of subraces for calliper-, visually- and volumeassessed gross shrinkage were broadly consistent. Dif-

\begin{tabular}{|c|c|c|c|c|c|c|c|}
\hline Trait & $\begin{array}{l}\text { Drying treatment. } \\
\qquad\left({ }^{\circ} \mathrm{C}\right)\end{array}$ & $\begin{array}{l}\text { Lcast-squarcs mean } \\
\text { (s.e.) }\end{array}$ & $\begin{array}{c}\text { F-ratio and } \\
\text { significance level } \\
\text { of differences } \\
\text { among subraces }\end{array}$ & $\begin{array}{l}\text { Additive variance } \\
\text { (s.e.) }\end{array}$ & $\begin{array}{c}\text { Phenotypic } \\
\text { variance (s.e.) }\end{array}$ & $h_{\mathrm{op}}^{2}(\mathrm{~s} . \mathrm{e})$ & $\mathrm{CV}_{\mathrm{a}}(\%)$ \\
\hline Calliper-assessed (\%) & 22 & $15.5(0.4)$ & $1.5^{\mathrm{ns}}$ & $5.4(3.5) \mathrm{ns}$ & $15.4(1.4)$ & $0.35(0.22)$ & 15.0 \\
\hline \multirow[t]{2}{*}{ tangential gross shrinkage } & 60 & $23.5(0.4)$ & $2.2 *$ & $10.3(4.1) * *$ & $17.5(1.7)$ & $0.59(0.21)$ & 13.6 \\
\hline & 105 & $28.4(0.4)$ & $3.4 * * *$ & $6.9(4.2) *$ & $19.0(1.8)$ & $0.36(0.21)$ & 9.2 \\
\hline Visually-assessed & 22 & NA & $1.1^{\text {is }}$ & $0.32(0.17)^{*}$ & $0.75(0.07)$ & $0.43(0.21)$ & NA \\
\hline \multirow[t]{2}{*}{ tangential gross shrinkage } & 60 & NA & $3.8 * * *$ & $0.33(0.17) *$ & $0.71(0.07)$ & $0.47(0.22)$ & NA \\
\hline & 105 & NA & $4.5 * * *$ & $0.29(0.15) *$ & $0.66(0.06)$ & $0.44(0.21)$ & NA \\
\hline Volume-assessed ( $\%$ ) & 22 & $17.4(0.2)$ & $2.0 *$ & $0.9(0.7) \mathrm{ns}$ & $3.3(0.3)$ & $0.28(0.22)$ & 5.5 \\
\hline \multirow[t]{2}{*}{ gross shrinkage } & 60 & $23.5(0.3)$ & $2.8 * *$ & $2.5(1.8) \mathrm{ns}$ & $8.0(0.7)$ & $0.31(0.22)$ & 6.7 \\
\hline & 105 & $27.6(0.3)$ & $3.1 * *$ & $2.9(2.0) \mathrm{ns}$ & $8.7(0.8)$ & $0.33(0.22)$ & 6.2 \\
\hline \multirow[t]{2}{*}{ Radial (\%) gross shrinkage } & 22 & $5.0(0.1)$ & $2.3 *$ & $0.1(0.2) \mathrm{ns}$ & $1.1(0.1)$ & $0.11(0.23)$ & 6.8 \\
\hline & 105 & $8.0(0.2)$ & $2.5 *$ & $0.1(0.6) \mathrm{ns}$ & $2.6(0.2)$ & $0.05(0.22)$ & 4.6 \\
\hline Basic density $\left(\mathrm{kg} \mathrm{m}^{-3}\right)$ & & $513(3)$ & $2.3 *$ & $749(305) * *$ & $1288(124)$ & $0.58(0.21)$ & 5.3 \\
\hline
\end{tabular}

Table 1. - Trait least-squares mean, F-ratio and significance level of differences among subraces, within-subrace additive variance and level of significance, phenotypic variance, narrow sense heritability, and coefficient of additive genetic variation $\left(\mathrm{CV}_{\mathrm{a}}\right)$ for each trait and drying treatment. Least-squares means are estimates for $12 \%$ of tree height and no decay.

NA Not applicable as data was normalised to have mean of zero.

ns Not significant, * $\mathrm{P}<0.05$, ** $\mathrm{P}<0.01$, *** $\mathrm{P}<0.001$. 
ferences between subraces in basic density were also found to be significant. Strzelecki Ranges and Flinders Island had the highest basic density and King Island and Southeast Tasmania the lowest (Table 2).
Significant additive variation within subraces was observed in calliper- and visually-assessed gross shrinkage under all drying treatments, except $22^{\circ} \mathrm{C}$ for calliper-assessment (Table 1). Estimates of heritability for

Table 2. - Subrace means (and standard errors) for measurements of gross shrinkage in samples dried at $105^{\circ} \mathrm{C}$ and basic density. Subraces with common letters for the same trait are not significantly different at $\mathrm{P}<0.05$ following Tukey-Kramer adjustment for multiple comparisons.

\begin{tabular}{|c|c|c|c|c|c|}
\hline \multirow[t]{2}{*}{ Subrace } & \multicolumn{4}{|c|}{ Gross shrinkage } & \multirow{2}{*}{$\begin{array}{c}\text { Basic density } \\
\left(\mathrm{kg} \mathrm{m}^{-3}\right)\end{array}$} \\
\hline & $\begin{array}{c}\text { Calliper- } \\
\text { assessed } \\
\text { tangential } \\
(\%)\end{array}$ & $\begin{array}{l}\text { Visually- } \\
\text { assessed } \\
\text { tangential }\end{array}$ & $\begin{array}{c}\text { Volume- } \\
\text { assessed } \\
(\%)\end{array}$ & $\begin{array}{l}\text { Radial } \\
(\%) \\
\end{array}$ & \\
\hline Cape Patton & $\begin{array}{c}31.3(1.1) \\
\mathrm{e}\end{array}$ & $\begin{array}{c}0.49(0.22) \\
\text { cd }\end{array}$ & $\begin{array}{c}29.2(0.8) \\
\mathrm{c}\end{array}$ & $\begin{array}{c}9.0(0.4) \\
b\end{array}$ & $\begin{array}{c}516(10) \\
\text { abc }\end{array}$ \\
\hline Eastern Otways & $\begin{array}{c}26.8(1.1) \\
\mathrm{ab}\end{array}$ & $\begin{array}{c}-0.17(0.20) \\
\mathrm{ab}\end{array}$ & $\begin{array}{c}26.4(0.7) \\
a\end{array}$ & $\begin{array}{c}7.9(0.4) \\
a\end{array}$ & $\begin{array}{c}518(9) \\
\mathrm{bc}\end{array}$ \\
\hline Flinders Island & $\begin{array}{c}28.3(0.9) \\
\text { abcd }\end{array}$ & $\begin{array}{c}-0.03(0.18) \\
\text { bc }\end{array}$ & $\begin{array}{c}27.5(0.6) \\
\mathrm{abc}\end{array}$ & $\begin{array}{c}7.5(0.3) \\
a\end{array}$ & $\begin{array}{c}520(8) \\
\mathrm{c}\end{array}$ \\
\hline King Island & $\begin{array}{c}30.2(0.9) \\
\text { de }\end{array}$ & $\begin{array}{c}0.58(0.17) \\
\mathrm{d}\end{array}$ & $\begin{array}{c}29.1(0.6) \\
\mathrm{c}\end{array}$ & $\begin{array}{c}8.8(0.3) \\
b\end{array}$ & $\begin{array}{c}493(8) \\
a\end{array}$ \\
\hline $\begin{array}{l}\text { Southern } \\
\text { Furneaux }\end{array}$ & $\begin{array}{c}26.6(1.1) \\
\mathrm{a}\end{array}$ & $\begin{array}{c}-0.29(0.21) \\
\mathrm{ab}\end{array}$ & $\begin{array}{c}26.6(0.7) \\
\mathrm{ab}\end{array}$ & $\begin{array}{c}8.0(0.4) \\
\mathrm{ab}\end{array}$ & $\begin{array}{c}517(9) \\
\mathrm{bc}\end{array}$ \\
\hline $\begin{array}{l}\text { Southern } \\
\text { Tasmania }\end{array}$ & $\begin{array}{c}27.9(1.1) \\
\text { abcd }\end{array}$ & $\begin{array}{c}-0.01(0.20) \\
b c\end{array}$ & $\begin{array}{c}26.9(0.7) \\
a b\end{array}$ & $\begin{array}{c}7.8(0.4) \\
a\end{array}$ & $\begin{array}{c}517(9) \\
\mathrm{bc}\end{array}$ \\
\hline $\begin{array}{l}\text { South-eastern } \\
\text { Tasmania }\end{array}$ & $\begin{array}{c}29.5(1) \\
\text { bcde }\end{array}$ & $\begin{array}{c}0.38(0.19) \\
\mathrm{cd}\end{array}$ & $\begin{array}{c}28.4(0.7) \\
b c\end{array}$ & $\begin{array}{c}8.1(0.4) \\
a b\end{array}$ & $\begin{array}{c}495(9) \\
\mathrm{ab}\end{array}$ \\
\hline Strzelecki Ranges & $\begin{array}{c}26.0(0.8) \\
\mathrm{a}\end{array}$ & $\begin{array}{c}-0.48(0.15) \\
a\end{array}$ & $\begin{array}{c}26.2(0.5) \\
a\end{array}$ & $\begin{array}{c}7.4(0.3) \\
a\end{array}$ & $\begin{array}{c}531(7) \\
\text { c }\end{array}$ \\
\hline Western Otways & $\begin{array}{c}27.3(0.9) \\
a b c\end{array}$ & $\begin{array}{c}-0.17(0.18) \\
a b\end{array}$ & $\begin{array}{c}26.9(0.6) \\
a b\end{array}$ & $\begin{array}{c}8.0(0.3) \\
a\end{array}$ & $\begin{array}{c}513(8) \\
\text { abc }\end{array}$ \\
\hline $\begin{array}{l}\text { Western } \\
\text { Tasmania }\end{array}$ & $\begin{array}{c}29.8(1.1) \\
\text { cde }\end{array}$ & $\begin{array}{c}0.43(0.2) \\
\mathrm{cd}\end{array}$ & $\begin{array}{c}28.4(0.7) \\
b c\end{array}$ & $\begin{array}{c}7.8(0.4) \\
a\end{array}$ & $\begin{array}{c}511(9) \\
\mathrm{abc}\end{array}$ \\
\hline
\end{tabular}

Table 3. - Subrace, genetic and phenotypic correlations (and standard errors) between temperature treatments for each measure of gross shrinkage.

\begin{tabular}{cclccc}
\hline Drying & Drying & Trait & \multicolumn{3}{c}{ Correlation } \\
\cline { 3 - 5 } trcat. 1 & trcat. 2 & & Subrace & Genetic & Phenotypic \\
& & & & & \\
\hline $22^{\circ} \mathrm{C}$ & $60^{\circ} \mathrm{C}$ & Calliper-assessed (\%) & $0.83(0.20)^{* *}$ & $1.10(0.16)^{* * * \S}$ & $0.74(0.04)^{* * *}$ \\
& & Visually-assessed & $\mathrm{NA}$ & $0.89(0.14)^{* * *}$ & $0.74(0.04)^{* * *}$ \\
& & Volume-assessed (\%) & $0.92(0.14)^{* * *}$ & $0.90(0.14)^{* * *}$ & $0.85(0.03)^{* * *}$ \\
& & Radial (\%) & $0.98(0.07)^{* * *}$ & $\mathrm{NA}$ & $0.80(0.04)^{* * *}$ \\
\hline $22^{\circ} \mathrm{C}$ & $105^{\circ} \mathrm{C}$ & Calliper-assessed (\%) & $0.73(0.24)^{*}$ & $1.15(0.31)^{* * *}$ & $0.53(0.05)^{* * *}$ \\
& & Visually-assessed & $\mathrm{NA}$ & $0.75(0.20)^{* * *}$ & $0.61(0.05)^{* * *}$ \\
& & Volume-assessed (\%) & $0.86(0.18)^{* *}$ & $0.93(0.21)^{* * *}$ & $0.73(0.04)^{* * *}$ \\
& & Radial (\%) & $0.95(0.11)^{* * *}$ & $\mathrm{NA}$ & $0.72(0.05)^{* * *}$ \\
\hline $60^{\circ} \mathrm{C}$ & $105^{\circ} \mathrm{C}$ & Calliper-assessed (\%) & $0.96(0.10)^{* * *}$ & $0.97(0.09)^{* * *}$ & $0.84(0.03)^{* * *}$ \\
& & Visually-assessed & $0.98(0.07)^{* * *}$ & $0.89(0.09)^{* * *}$ & $0.86(0.03)^{* * *}$ \\
& & Volume-assessed (\%) & $0.97(0.09)^{* * *}$ & $1.01(0.06)^{* * *}$ & $0.92(0.03)^{* * *}$ \\
& & Radial (\%) & $0.95(0.11)^{* * *}$ & $\mathrm{NA}$ & $0.83(0.04)^{* * *}$ \\
\hline
\end{tabular}

NA Correlations were not calculated if one or more of the traits being compared did not reveal significant genetic variation among subraces or families within subraces at the $\mathrm{P}=0.200$ level.

* $\mathrm{P}<0.05$, ** $\mathrm{P}<0.01$, *** $\mathrm{P}<0.001$.

$\S$ Correlation estimate is outside the parameter space. 
Table 4. - Subrace, genetic and phenotypic correlations (and standard errors) among measures of gross shrinkage under the $105^{\circ} \mathrm{C}$ drying treatment.

\begin{tabular}{|c|c|c|c|c|}
\hline $\begin{array}{l}\text { Gross shrinkage } \\
\text { mcasurcment } 1\end{array}$ & $\begin{array}{l}\text { Gross shrinkagc } \\
\text { mcasurement } 2\end{array}$ & Subracc & Genctic & Phonotypic \\
\hline Calliper-assessed (\%) & Visually-assessed & $0.97(0.09)^{* * * *}$ & $0.95(0.09)^{* * *}$ & $0.86(0.03)^{* * * *}$ \\
\hline Calliper-assessed (\%) & Volume-assessed $(\%)$ & $0.98(0.07)^{* * *}$ & $1.36(0.33)^{* * * \S}$ & $0.67(0.05)^{* * *}$ \\
\hline Calliper-assessed (\%) & Radial (\%) & $0.75(0.23)^{*}$ & NA & $0.22(0.06)^{* * *}$ \\
\hline Visually-assessed & Volume-assessed (\%) & $0.97(0.09)^{* * *}$ & $1.12(0.19)^{* * * \S}$ & $0.74(0.04)^{* * *}$ \\
\hline Visually-assessed & Radial (\%) & $0.73(0.24)^{*}$ & NA & $0.34(0.06)^{* * *}$ \\
\hline Volume-assessed (\%) & Radial (\%) & $0.77(0.23)^{* *}$ & $\mathrm{~N} \Lambda$ & $0.50(0.06)^{* * *}$ \\
\hline \multicolumn{5}{|c|}{$\begin{array}{l}\text { NA Correlations were not calculated if one or more of the traits being compared did not reveal } \\
\text { significant genetic variation among families within subraces at the } \mathrm{P}=0.200 \text { level. } \\
\text { \& } \mathrm{P}<0.05 \text {, } * * \mathrm{P}<0.01, * * * \mathrm{P}<0.001 \text {. } \\
\text { Correlation estimate is outside the parameter space. }\end{array}$} \\
\hline
\end{tabular}

these traits were all greater than or equal to 0.35 . Coefficients of additive genetic variation were greatest for the calliper assessment method. There was no obvious trend in heritabilities or coefficients of additive genetic variation with drying temperature. No significant additive genetic variation within subrace was observed in volume-assessed $(\mathrm{P}=0.108,0.082$ and 0.066 under the $22^{\circ} \mathrm{C}, 60^{\circ} \mathrm{C}$ and $105^{\circ} \mathrm{C}$ drying treatments respectively) or radial gross shrinkage $(\mathrm{P}=0.320,0.500$ and 0.405 respectively). However, significant additive genetic variation within subrace was observed in basic density.

All calculated subrace, genetic and phenotypic correlations for gross shrinkage among drying treatments were positive and significantly different to zero (Table 3). Excluding radial gross shrinkage measurements, no

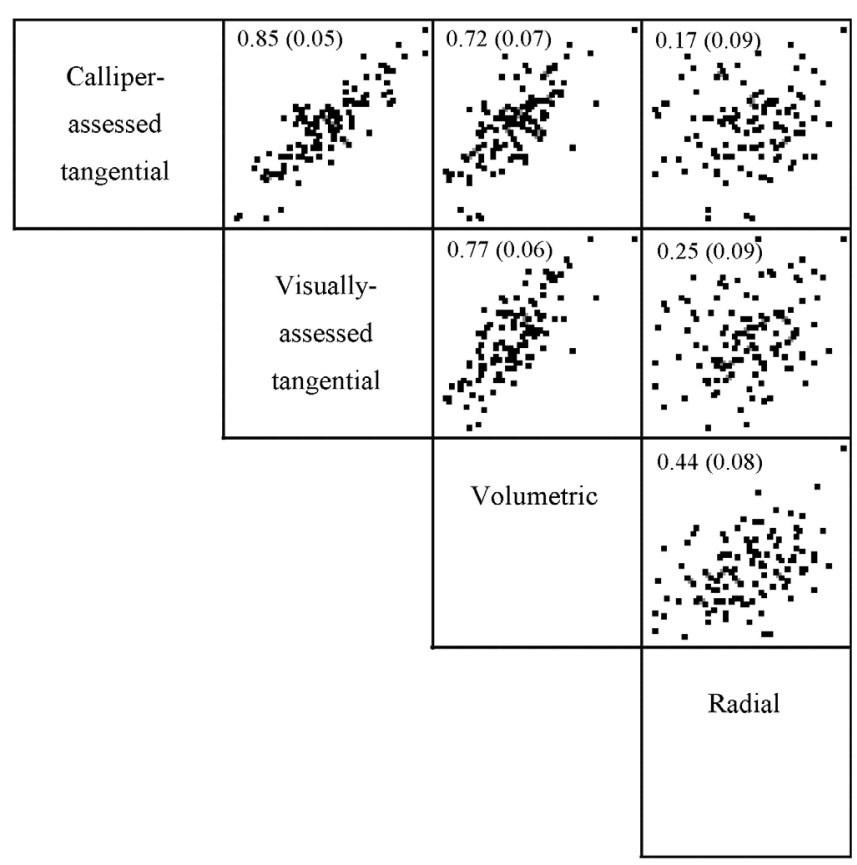

Figure 1. - Scatter matrix of family within subrace best linear unbiased predictions (BLUPs) for measurements of gross shrinkage under the $105^{\circ} \mathrm{C}$ drying treatment derived from univariate analyses. Pearson correlations (and standard errors) between family BLUPs are shown. genetic correlations between drying treatments were significantly different to one $(P \geq 0.076)$. Some of these estimated genetic correlations were outside the parameter space (i.e. they were greater than one), probably due to the relatively small sample size. However, the hypothesis that genetic correlations between drying treatments were positive and strong was further supported by strong and positive $(\geq 0.60)$ Pearson correlations between family within-subrace best linear unbiased predictions (BLUPs) derived from univariate analyses (data not shown).

Although moderate to strong using all methods of gross-shrinkage assessment, phenotypic correlations were lowest $(0.53-0.72)$ between the least similar drying treatments (i.e. $22^{\circ} \mathrm{C}$ and $105^{\circ} \mathrm{C}$ ). Phenotypic correlations between the oven-dried treatments (i.e. $60^{\circ} \mathrm{C}$ and $105^{\circ} \mathrm{C}$ ) were greater than or equal to 0.83 .

Correlations among measurement techniques were examined under the $105^{\circ} \mathrm{C}$ drying treatment, the treatment most commonly adopted in breeding programs as it is used to assess basic density (DownEs et al., 1997; RAYMOND and APIOLAZA, 2004). Subrace correlations between measures of gross shrinkage were positive and significantly different to zero (Table 4). However, correlations with radial gross shrinkage were not as strongly positive $(\leq 0.77)$ as those among other measurement techniques, which were all very close to one $(\geq 0.97)$.

Genetic correlations between measures of calliper-, visually- and volume-assessed gross shrinkage were all greater than or equal to 0.95 and significantly different to zero but not significantly different to one $(\mathrm{P} \geq 0.065$; Table 4). Although some estimated genetic correlations were outside the parameter space, Pearson correlations between family within subrace BLUPs were 0.72 or greater, supporting the hypothesis that additive genetic relationships among these traits were strong (Figure 1).

All phenotypic correlations among measurement techniques were positive and significantly different to zero (Table 4). However, correlations with radial gross shrinkage were weaker than those among other measurement techniques.

All subrace correlations between basic density and measures of gross shrinkage assessed on samples dried 
Table 5. - Correlations (and standard errors) between sample basic density and measures of gross shrinkage in samples dried at $105^{\circ} \mathrm{C}$.

\begin{tabular}{lccc}
\hline Trait & \multicolumn{3}{c}{ Correlation } \\
\cline { 2 - 4 } & Subrace & Genetic & Phenotypic \\
\hline Callipcr-assessed (\%) & $-0.60(0.28)^{\mathrm{ns}}$ & $-0.88(0.27)^{* *}$ & $-0.50(0.05)^{* * *}$ \\
Visually-assessed & $-0.75(0.23)^{*}$ & $-0.63(0.24)^{* *}$ & $-0.51(0.05)^{* * *}$ \\
Volume-assessed (\%) & $-0.68(0.26)^{*}$ & $-0.49(0.35)^{\mathrm{ns}}$ & $-0.35(0.06)^{* * *}$ \\
Radial $(\%)$ & $-0.59(0.29)^{\mathrm{ns}}$ & $\mathrm{N} \Lambda$ & $-0.27(0.06)^{* * *}$ \\
\hline NA & Correlations were not calculated if one or more of the traits being com- \\
\multicolumn{2}{l}{ pared did not reveal significant genetic variation among families within } \\
subraces at the $\mathrm{P}=0.200$ level. \\
ns
\end{tabular}

at $105^{\circ} \mathrm{C}$ were negative (Table 5) but only correlations with visually- and volume-assessed gross shrinkage were significantly different to zero. The genetic correlations of basic density with calliper- and visuallyassessed gross shrinkage were strongly negative and significantly different to zero and neither was significantly different to minus one $(\mathrm{P} \geq 0.083)$. Phenotypic correlations between basic density and all gross shrinkage traits were negative and significantly different to zero.

\section{Discussion}

\section{Drying treatments}

Although normal shrinkage was confounded with collapse in this study of gross shrinkage, it is likely that only small differences in normal shrinkage were present among drying treatments, because samples were allowed to stabilise to equilibrium moisture content in a common environment prior to gross shrinkage measurement. The observed increase in gross shrinkage at higher drying temperatures was consistent with there being greater collapse in wood dried under more harsh conditions (CHAFE, 1992). However, even under the mildest drying treatment (i.e. $22^{\circ} \mathrm{C}$ ), gross shrinkage was substantially greater than previous estimates of normal shrinkage in E. globulus 12-mm wood cores (RAYMOND et $a l ., 2004)$, indicating the presence of collapse and or tension wood. Accordingly, the findings of this study may not be applicable to very mild drying treatments, under which little or no collapse might be expressed.

Although the $105^{\circ} \mathrm{C}$ drying treatment was the only drying treatment to reveal significant subrace difference for all measures of gross shrinkage, the strongly positive subrace and genetic correlations among drying treatments indicated that the relative performances of genotypes were similar across treatments. From a practical perspective, this indicates that different drying treatments could be used interchangeably in breeding programs with little reduction in selection efficiency and that breeders could adopt drying treatments according to the requirements of other selection traits. For example, the $105^{\circ} \mathrm{C}$ drying treatment would be appropriate if basic density was to be assessed but inappropriate if near infrared spectroscopy (NIR) was to be undertaken on samples after drying (Downes et al., 1997).
In a study of $E$. nitens shrinkage properties, additive genetic variation in volume-assessed gross shrinkage was principally explained by additive genetic variation in recoverable collapse (HAMILTON et al., 2009). It is likely that this is also the case in E. globulus. However, a study designed to examine genetic variation in the separate components of gross shrinkage is required to definitively determine the underlying reasons for the strong genetic correlations observed in gross shrinkage among drying treatments.

\section{Genetic variation in gross shrinkage}

The significant differences between subraces in all measures of gross shrinkage indicated that gross shrinkage could be reduced through subrace selection. Furthermore, significant additive variances and moderate to very high heritabilities in calliper- and visuallyassessed gross shrinkage indicated that tangential gross shrinkage was under strong additive genetic control and could be reduced through selection within subraces. In addition, the very strong subrace, genetic and phenotypic correlations between these two methods of assessment indicated that these measurement techniques could be used interchangeably in breeding programs with little reduction in selection efficiency. However, both calliperand visual assessment of gross shrinkage were time consuming in samples that did not exhibit visually obvious shrinkage (e.g. in samples dried under the $22^{\circ} \mathrm{C}$ drying treatment), as it was difficult to rank samples or identify points of maximum shrinkage. Furthermore, the visual-assessment technique would not allow comparison of gross shrinkage levels across generations, sites or ages as it is based on a ranking of samples rather than a quantified measure of the magnitude of gross shrinkage.

The very strong subrace, genetic and phenotypic correlations of volume-assessed gross shrinkage with calliper- and visually-assessed gross shrinkage implied that volume-assessment could also be used to select against tangential gross shrinkage. However, additive genetic variance within subraces in volume-assessed gross shrinkage was not significant in this study, although a significant difference between subraces was observed. This method has revealed significant additive genetic variation in $E$. nitens (HAMILTON et al., 2004; HAMiLton et al., 2009) and a larger-scale study is 
required to definitively determine the extent to which volume-assessed gross shrinkage is under additive genetic control in $E$. globulus, particularly given that volume assessment has practical advantages over other measurement techniques. Volume-assessment is rapid, particularly if green-sample volumes are already assessed for the purpose of density measurement, and does not require the visual identification of points of maximum shrinkage.

The lack of significant additive genetic variation in radial gross shrinkage indicated that selection within subraces for reduced radial gross shrinkage would not result in significant genetic gains and, by implication, that selection within subraces for reduced tangential gross shrinkage would reduce the difference between tangential and radial gross shrinkage (i.e. shrinkage anisotropy). Shrinkage anisotropy is the principal cause of cupping in backsawn boards and can result in face checking if boards are restrained from cupping (SvENSSON and MARTENsson, 1999). However, it is possible that additive genetic variation was present in radial gross shrinkage but not detected in this study due to the relatively small sample size.

\section{Relationship between gross shrinkage and basic density}

The relative performances of subraces in terms of basic density were broadly consistent with previously published results (DUTKOwski and PoTTs, 1999; MUNERI and RAYMOND, 2000; LopEZ et al., 2001). Estimates of heritability for basic density were also similar to previous estimates (VOLKER et al., 1990; MACDONALD et al., 1997; MUNERI and RAYMOND, 2000; RAYMOND et al., 2001; LOPEZ et al., 2002).

The negative subrace, genetic and phenotypic correlations between basic density and measures of gross shrinkage were consistent with the hypothesis that much of the gross shrinkage observed in this study was due to collapse. In other eucalypt species, trees of relatively low basic density have generally been observed to exhibit relatively high levels of collapse and low levels of normal shrinkage (CHAFE, 1992; ILIC, 1999; HAMILTON et al., 2009). The strongly negative genetic correlations between basic density and calliper- and visuallyassessed gross shrinkage indicated that selection for increased basic density, as currently takes place in pulpwood breeding programs (RAYMOND and APIOLAZA, 2004), would result in a favourable correlated response in tangential gross shrinkage. Significant and negative genetic correlations between core gross shrinkage and basic density have also been observed in E. nitens (HAMILTON et al., 2004; KUBE and RAYMOND, 2005). Although these findings indicate that indirect genetic gains could be achieved in both tangential gross shrinkage and basic density by selecting trees according to either trait, direct assessment for both traits may be justified in breeding programs given the low cost of the laboratory-based component of their assessment.

In conclusion, subrace and within subrace selection against tangential gross shrinkage is likely to result in significant genetic gains in E. globulus. Although a larger-scale study is required to definitively determine the extent of within-subrace genetic variation in volumeassessed gross shrinkage, the very strong genetic correlations observed among calliper-, visually and volumeassessed gross shrinkage indicated that practical considerations should determine which of these methods of assessment is adopted for breeding purposes. None of the measurement techniques examined required specialised skills or equipment but the assessment of volumetric shrinkage was the most rapid of those examined for samples lacking visually-obvious gross shrinkage, such as those dried under the $22^{\circ} \mathrm{C}$ drying treatment. Although there was significant variation at the subrace level in radial gross shrinkage, there was no evidence of exploitable within subrace genetic variation in this trait, suggesting that selection against tangential shrinkage is also likely to reduce shrinkage anisotropy. Strong subrace and genetic correlations among drying treatments indicated that they could be adopted interchangeably in breeding programs with little reduction in selection efficiency. There was evidence that selection for increased basic density would result in a correlated reduction in gross shrinkage which has favourable implications for genetic improvement programs with concurrent pulpwood and solid-wood breeding objectives.

\section{Acknowledgments}

Funding for this project was provided by Australian Research Council linkage grants C00107465 (supported by the Southern Tree Breeding Association, STBA) and LP0453704 (supported by the Gunns Ltd., the Forests and Forest Industries Council of Tasmania, the STBA, Forestry Tasmania, RAIZ, seedEnergy Pty. Ltd., Timbercorp Ltd. and WA Plantation Resources Ltd.) and the CRC for Sustainable Production Forestry (1997-2005). We acknowledge the assistance of RENÉ VAILLANCOURT, Greg Dutkowski, Luis Apiolaza, Tony Blythe, Paul Tilyard, Leigh Johnson, Jonathon Cock, Bruce Greaves, Kelsey Joyce, Robert Lewis, Renate Van Riet and Tim Watson. We thank Gunns Ltd for access to the field trial and use of their facilities.

\section{References}

ApiolazA, L. A., C. A. Raymond and B. J. Yeo (2005): Genetic variation of physical and chemical wood properties of Eucalyptus globulus. Silvae Genetica 54: 160-166.

BANDARA, K. M. A. (2006): Genetic improvement of solid wood product value of subtropical eucalypts: a case study of Eucalyptus grandis and E. dunnii. Unpublished $\mathrm{PhD}$ Thesis, Australian National University.

Borralho, N. M. G., P. P. Cotterill and P. J. Kanowski (1993): Breeding objectives for pulp production of Eucalyptus globulus under different industrial cost structures. Canadian Journal of Forest Research 23: 648-656.

Brennan, G. K., R. A. Hingston and R. W. Moore (2004): Processing 17-year-old Tasmanian blue gum sawlogs grown at wide spacing. Australian Forestry 67: 240-246.

Chafe, S. C. (1992): Collapse: an introduction. CSIRO, Division of Forest Products. 
Dickson, R. L., C. A. Raymond, W. Joe and C. A. WilkinSON (2003): Segregation of Eucalyptus dunnii logs using acoustics. Forest Ecology and Management 179: 243-251.

Downes, G. M., I. L. Hudson, C. A. Raymond, G. H. Dean, A. J. Michell, L. R. Schimleck, R. Evans and A. Muneri (1997): Sampling plantation eucalypts for wood and fibre properties. CSIRO Publishing, Melbourne, Victoria.

Dutkowski, G. W. and B. M. PotTs (1999): Geographic patterns of genetic variation in Eucalyptus globulus ssp. globulus and a revised racial classification. Australian Journal of Botany 47: 237-263.

FALCONER, D. S. and T. F. C. MACKAY (1996): Introduction to quantitative genetics. Longman, Harlow.

GARDINER, C. A. and D. F. CRAWFORD (1987): Seed collections of Eucalyptus globulus subsp. globulus for tree improvement purposes. CSIRO Division of Forest Research.

Gardiner, C. A. and D. F. CRAWFord (1988): Seed collections of Eucalyptus globulus subsp. globulus for tree improvement purposes. CSIRO Division of Forestry and Forest Products.

Gilmour, A. R., B. J. Gogel, B. R. Cullis and R. ThompSON (2006): ASReml User Guide Release 2.0. VSN International Ltd, Hemel Hempstead, UK.

Greaves, B. L. and N. M. G. Borralho (1996): The influence of basic density and pulp yield on the cost of eucalypt kraft pulping: a theoretical model for tree breeding. Appita Journal 49: 90-93.

Greaves, B. L., N. M. G. Borralho and C. A. Raymond (1997): Breeding objective for plantation eucalypts grown for production of kraft pulp. Forest Science 43: 465-472.

Greaves, B. L., G. Dutkowski and T. McRae (2004a): Breeding objectives for Eucalyptus globulus for products other than kraft pulp. P. 175-180. In: Eucalyptus in a changing world. Proceedings of an IUFRO conference, Aveiro, Portugal. 11-15 October.

Greaves, B. L., M. Hamilton, D. Pilbeam and G. DUTKOWSKI (2004b): Genetic variation in commercial properties of six and fifteen year-old Eucalyptus globulus. P. 97-102. In: Eucalyptus in a changing world. Proceedings of an IUFRO conference, Aveiro, Portugal. 11-15 October.

GRIFFIN, A. R. and P. P. CotTeRILL (1988): Genetic variation in growth of outcrossed, selfed and open-pollinated progenies of Eucalyptus regnans and some implications for breeding strategy. Silvae Genetica 37: 124-131.

Hamilton, M. G., B. L. Greaves, B. M. Potts and G. W. DuTKowsKI (2007): Patterns of longitudinal within-tree variation in pulpwood and solidwood traits differ among Eucalyptus globulus genotypes. Annals of Forest Science 64: 831-837.

Hamilton, M. G., B. M. Potts, C. E. Harwood, L. ApioLAZA and P. GORE (2004): Comparison of non-destructive assessment techniques for shrinkage and collapse in Eucalyptus nitens. P. 686-687. In: Eucalyptus in a changing world. Proceedings of an IUFRO conference, Aveiro, Portugal. 11-15 October.

Hamilton, M. G., C. A. Raymond, C. E. Harwood and B. M. PotTs (2009): Genetic variation in Eucalyptus nitens pulpwood and wood shrinkage traits. Tree Genetics and Genomes 5: 307-316.

Hamilton, M. G., C. A. Raymond and B. M. Potts (2008): Short note: The genetic correlation between air-dried density and basic density in Eucalyptus nitens wood cores. Silvae Genetica 57: 210-212.
ILIC, J. (1999): Shrinkage-related degrade and its association with some physical properties in Eucalyptus regnans F-Muell. Wood Science and Technology 33 425-437.

Kube, P. D. and C. A. Raymond (2005): Breeding to minimise the effects of collapse in Eucalyptus nitens. Forest Genetics 12: 23-34.

Lopez, G. A., B. M. Potts, G. W. Dutkowski, L. A. ApioLAZA and P. E. GELID (2002): Genetic variation and inter-trait correlations in Eucalyptus globulus base population trials in Argentina. Forest Genetics 9: 217-231.

Lopez, G. A., B. M. PotTs, G. W. Dutkowski and J. M. R. TRAVERSO (2001): Quantitative genetics of Eucalyptus globulus: Affinities of land race and native stand localities. Silvae Genetica 50: 244-252.

MacDonald, A. C., N. M. G. Borralho and B. M. Potts (1997): Genetic variation for growth and wood density in Eucalyptus globulus spp. globulus in Tasmania (Australia). Silvae Genetica 46: 236-241.

McKenzie, H. M., C. J. A. Shelbourne, M. O. Kimberley, R. B. McKinley and R. A. J. BRitTon (2003): Processing young plantation-grown Eucalyptus nitens for solidwood products. 2: Predicting product quality from tree, increment core, disc, and 1-m billet properties. New Zealand Journal of Forestry Science 33: 79-113.

Moore, R. W., G. R. Siemon, P. Eckersley and R. A. Hingston (1996): Sawlogs from 13 year old Eucalyptus globulus - Management, recovery and economics. P. 219-231. In: Plantations and Farm Forestry - Investing in Future Wood Supply, Australian Forest Growers Biennial Conference, Mount Gambier, South Australia. 9-12 September.

Muneri, A. and C. A. RAYMOND (2000): Genetic parameters and genotype-by-environment interactions for basic density, pilodyn penetration and stem diameter in Eucalyptus globulus. Forest Genetics 7: 317-328.

Nolan, G., T. InNEs, A. REDMAN and R. McGavin (2003): Australian hardwood drying best practice manual. PN01.1307, Forest and Wood Products Research and Development Corporation.

Nolan, G., R. Washusen, S. Jennings, B. Greaves and M. PARSONS (2005): Eucalypt plantations for solid wood products in Australia - A review. PN04.3002, Forest and Wood Products Research and Development Corporation.

NuTTO, L. and M. C. T. VAZQUEZ (2004): High quality eucalyptus sawlog production. P. 658-666. In: Eucalyptus in a changing world. Proceedings of an IUFRO conference, Aveiro, Portugal. 11-15 October.

Parsons, M., M. Gavran and J. Davidson (2006): Australia's plantations 2006. Bureau of Rural Sciences, Commonwealth of Australia.

Potts, B., R. E. Vaillancourt, G. Jordan, G. W. Dutkowski, J. da Costa E Silva, G. E. McKinnon, D. A. Steane, P. Volker, G. A. Lopez, L. Apiolaza, Y. Li, C. MARques and N. BorRalho (2004): Exploration of the Eucalyptus globulus gene pool. P. 46-61. In: Eucalyptus in a changing world. Proceedings of an IUFRO conference, Aveiro, Portugal. 11-15 October.

RAYMOND, C. A. (2000): Tree breeding issues for solid wood production. P. 310-316. In: The Future of Eucalypts for Wood Products. Proceedings of an IUFRO Conference, Launceston, Tasmania. 19-24 March.

RAYMOND, C. A. and L. APIOLAZA (2004): Incorporating wood quality and deployment traits in Eucalyptus globulus and Eucalyptus nitens. In: Plantation forest biotechnology for the $21^{\text {st }}$ century. (Ed. C. WALTER and M. CARson.) pp. 87-99. Research Signpost, Kerala, India. 
RaYmond, C. A., L. SAVAGE and C. HARWOOD (2004): Longitudinal patterns of volumetric shrinkage and collapse in Eucalyptus globulus and E. nitens. P. 701. In: Eucalyptus in a changing world. Proceedings of an IUFRO conference, Aveiro, Portugal. 11-15 October.

Raymond, C. A., L. R. Schimleck, A. Muneri and A. J. MiCHELL (2001): Genetic parameters and genotype-byenvironment interactions for pulp yield predicted using near infrared reflectance analysis and pulp productivity in Eucalyptus globulus. Forest Genetics 8: 213-224.

Svensson, S. and A. MARTEnsson (1999): Simulation of drying stresses in wood. Part I: comparison between one- and two-dimensional models. Holz als Roh- und Werkstoff 57: 129-136.

TAPPI (1989): Basic density and moisture content of pulpwood. T258 om-98, Technical Association of the Pulp and Paper Industries (TAPPI)

Volker, P. W., C. A. Dean, W. N. Tibbits and I. C. RavenWOOD (1990): Genetic parameters and gains expected from selection in Eucalyptus globulus in Tasmania. Silvae Genetica 39: 18-21.

WALKER, J. C. F. (2006): Primary wood processing: principles and practice. Second edition. Springer, Dordrecht, The Netherlands.
Washusen, R. (2004): Processing pruned and unpruned Eucalyptus globulus managed for sawlog production to produce high value products. PN03.1315, Australian Government, Forest and Wood Products Research and Development Corporation.

Washusen, R., P. Blakemore, R. Northway, P. Vinden and G. WAUGH (2000): Recovery of dried appearance grade timber from Eucalyptus globulus Labill. grown in plantations in medium rainfall areas of the southern Murray-Darling Basin. Australian Forestry 63: 277-283.

WASHUSEN, R. and J. ILIC (2001): Relationship between transverse shrinkage and tension wood from three provenances of Eucalyptus globulus Labill. Holz als Roh- und Werkstoff 59: 85-93.

WAUGH, G. (2004): Growing Eucalyptus globulus for highquality sawn products. P. 79-84. In: Eucalyptus in a changing world. Proceedings of an IUFRO conference, Aveiro, Portugal. 11-15 October.

WAUGH, G. and J. YANG (1994): Opportunities for sawn products from Tasmanian plantation eucalypts. P. 215-220. In: Faces of Farm Forestry. Proceedings of an Australian Forest Growers Conference, Launceston, Tasmania. 